An azole, an amide and a limonoid from Vepris uguenensis (Rutaceae)

Peter K. Cheplogoi, Dulcie A. Mulholland", Philip H. Coombes, Milijaona Randrianarivelojosia

The novel limonoid, methyl uguenesonate, novel azole, uguenenazole, and novel amide, uguenenonamide, together with the known furoquinoline alkaloids flindersiamine and maculosidine, and

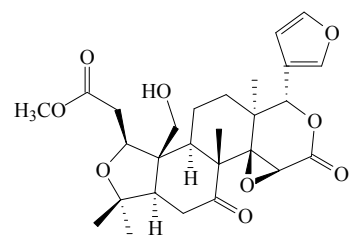
syringaldehyde have been isolated from the root of the East African Rutaceae Vepris uguenensis. 


\section{An azole, an amide and a limonoid from Vepris uguenensis (Rutaceae)}

Peter K Cheplogoi ${ }^{1,2}$, Dulcie A Mulholland ${ }^{1,3^{*}}$, Philip H Coombes ${ }^{1}$, Milijaona

Randrianarivelojosia ${ }^{1,4}$

${ }^{1}$ School of Chemistry, University of KwaZulu-Natal, Durban, 4041, South Africa

${ }^{2}$ Department of Chemistry, Egerton University, P.O. Box 536-20107, Njoro, Kenya

${ }^{3}$ Natural Products Research Group, Division of Chemistry, Faculty of Health and Medical Sciences, University of Surrey, Guildford, Surrey, GU2 7XH, United Kingdom

${ }^{4}$ Malaria Research Group, BP 1274 - Antananarivo (101) - Institut Pasteur de Madagascar

Keywords: Vepris uguenensis; Rutaceae; Limonoid; Azole; Amide; Furoquinoline alkaloid; Methyl uguenesonate; Uguenenzole; Uguenenonamide, Flindersiamine; Maculosidine, Antimalarial activity

Corresponding author: d.mulholland@surrey.ac.uk Tel: +44 (0)1483 686827. Fax: +44 (0)1483 6868. 


\section{Abstract:}

The novel limonoid, methyl uguenesonate, novel azole, uguenenazole, and novel amide, uguenenonamide, together with the known furoquinoline alkaloids flindersiamine and maculosidine, and syringaldehyde have been isolated from the root of the East African Rutaceae Vepris uguenensis. While methyl uguenesonate and the furoquinoline alkaloids displayed mild antimalarial activity, the azole and amide were completely inactive. 


\section{Introduction}

The genus Vepris Comm. ex A. Juss. comprises some 80 species of shrubs and trees, occurring primarily in tropical Africa, Zanzibar, Madagascar and the Mascarene Islands, and to a lesser extent in tropical Arabia and southwest India (Chaturvedula et al., 2003).

Ethnomedicinally, species of the genus Vepris are employed in the treatment of a diverse range of ailments, including pneumonia, lung diseases and kidney disorders (Hedberg et al., 1983), eye troubles, cardiac pains, coughs, colds and influenza (Chhabra et al., 1991; GuribFakim et al., 1993), headache (Arnold and Gulumian, 1984), menorrhegia and infertility (Steenkamp, 2003), and as an aphrodisiac (Poitou et al., 1995), diuretic and antipyretic (Gomes et al., 1994), astringent and fortifier (Vera et al., 1990), tonic for angina and rheumatism (Gurib-Fakim et al., 1993), and both orally and externally as a treatment for malaria (Gessler et al., 1994, 1995). Vepris uguenensis Engl., the subject of the present study, is known is "chemchir" by the Pokot tribe of Kenya, who use it as an antimalarial (Cheplogoi, pers. comm.).

Fifteen Vepris species have previously been investigated: V. ampody H.Perr. (Kan-Fan et al., 1970), V. bilocularis (Wight et Arn.) Engl. (Govindachari and Sundararajan, 1961; Govindachari, et al., 1964; Ganguly et al., 1966; Brader et al., 1996), V. dainellii (Pic. Serm.) Kokwaro (Dagne et al., 1988), V. elliotii (Radlk.) I. Verd. (Poitou et al., 1995), V. fitoravina H.Perr. (Koffi et al., 1987), V. glomerata (F.Hoff.) Engl. (Dagne et al., 1988), V. heterophylla R. Let. (Gomes et al., 1983, 1994; Moulis et al., 1994; Sidibe et al., 2001), V. leandriana H.Perr. (Rakotondraibe et al.,2001), V. louisii (Ayafor et al., 1980, 1981, 1982a, 1982b, 1982c; Ngadjui et al., 1982), V. macrophylla (Baker) I. Verd. (Koffi et al., 1987), V. madagascarica (Baill.) H.Perr. (Billet and Favre-Bonvin, 1973), V. pilosa (Baker) I. Verd. (Haensel and Cybulski, 1978), V. punctata (I.Verd.) W. Mziray (Chaturvedula et al., 2003), V. sclerophylla H.Perr. (Rasoanaivo et al., 1999) and V. stolzii I.Verd. (Khalid and Waterman, 1982). Although furoquinoline alkaloids are the most common isolates, acridone and quinol-2-one alkaloids, limonoids and triterpenoids have also been found (Dictionary of Natural Products, 2007). 


\section{Results and Discussion}

A novel limonoid derivative, methyl uguenesonate (1), a novel azole, uguenenzole (2), a novel amide, uguenenonamide (3) (Figure 1), the known furoquinoline alkaloids flindersiamine (4) and maculosidine (5), and syringaldehyde (6), were isolated from the dichloromethane extract of the roots of Vepris uguenensis.

The HREIMS of methyl uguenesonate (1) showed a molecular ion peak at $\mathrm{m} / \mathrm{z} 502.2203$, corresponding to the molecular formula $\mathrm{C}_{27} \mathrm{H}_{34} \mathrm{O}_{9}$ and indicating 11 double bond equivalents. Analysis of the 2D NMR spectra, and comparison with literature values (Ng et al., 1987; Patra et al., 1988) for limonin showed that (1) also possessed the furan ring $\left(\delta_{\mathrm{H}} 7.39(1 \mathrm{H}, \mathrm{s})\right.$, H-21; $\delta_{\mathrm{H}} 6.30(1 \mathrm{H}, \mathrm{s}), \mathrm{H}-22 ; \delta_{\mathrm{H}} 7.37(1 \mathrm{H}, \mathrm{s}), \mathrm{H}-23 ; \delta_{\mathrm{C}} 141.1,109.8,143.1$ (each CH), C-21, C-22, C-23; $\left.\delta_{\mathrm{C}} 120.3, \mathrm{C}, \mathrm{C}-20\right), 14 \beta, 15 \beta$-epoxy ring D lactone $\left(\delta_{\mathrm{H}} 5.57(1 \mathrm{H}, \mathrm{s}), \mathrm{H}-17 ; \delta_{\mathrm{H}}\right.$ $3.91(1 \mathrm{H}, \mathrm{s}), \mathrm{H}-15 ; \delta_{\mathrm{C}} 78.1(\mathrm{CH}), \mathrm{C}-17$; $\delta_{\mathrm{C}} 167.5(\mathrm{C}), \mathrm{C}-16 ; \delta_{\mathrm{C}} 55.4(\mathrm{CH}), \mathrm{C}-15 ; \delta_{\mathrm{C}} 69.5(\mathrm{C})$, C-14), C-7 ketone $\left(\delta_{\mathrm{C}} 211.8(\mathrm{C})\right)$, contracted ring A $\left(\delta_{\mathrm{H}} 4.15(1 \mathrm{H}, \mathrm{m}), \mathrm{H}-3 ; \delta_{\mathrm{C}} 74.7(\mathrm{CH}), \mathrm{C}-\right.$ 3 ; $\left.\delta_{\mathrm{C}} 83.8(\mathrm{C}), \mathrm{C}-4\right)$, and four quaternary methyl groups $\left(\delta_{\mathrm{H}} 1.17,1.10,1.24,1.39\right.$ (each $3 \mathrm{H}$, s), 3H-18, 3H-28, 3H-29, 3H-30; $\delta_{\mathrm{C}} 19.6,24.2,28.9,16.9$ (each $\left.\mathrm{CH}_{3}\right)$, C-18, C-28, C-29, C$30)$ of the limonin skeleton. However, although the signals of the $\mathrm{C}-19$ oxymethylene $\left(\delta_{C}\right.$ $\left.68.7\left(\mathrm{CH}_{2}\right)\right)$ and ester carbonyl $\left(\delta_{\mathrm{C}} 173.6(\mathrm{C})\right)$ carbons were still present in $(\mathbf{1})$, they differed from the literature values; additionally, while (1), relative to limonin, lacked a double bond equivalent, it possessed both an additional carbon and additional oxygen atom, which appeared as the signals of a carbomethoxy group $\left(\delta_{\mathrm{H}} 3.72(3 \mathrm{H}, \mathrm{s}) ; \delta_{\mathrm{C}} 52.3\left(\mathrm{CH}_{3}\right)\right)$. Methyl uguenesonate, with structure (1) in Figure 1 below, is thus a novel derivative of limonin in which the ring A' lactone has undergone cleavage to give the hydroxy-acid, followed by methyl esterification.

The HREIMS of uguenenazole (2) showed a molecular ion peak at $\mathrm{m} / \mathrm{z} 251.0948$, corresponding to the molecular formula $\mathrm{C}_{16} \mathrm{H}_{13} \mathrm{NO}_{2}$ and 11 double bond equivalents. Inspection of the ${ }^{1} \mathrm{H},{ }^{13} \mathrm{C}$ and $2 \mathrm{D}$ NMR spectra showed (2) to possess two aromatic rings, one monosubstituted $\left(\delta_{\mathrm{H}} 8.08(2 \mathrm{H}, \mathrm{dd}, J=8.1,1.7 \mathrm{~Hz}), \mathrm{H}-2^{\prime} / 6^{\prime} ; \delta_{\mathrm{H}} 7.46(2 \mathrm{H}, \mathrm{m}), \mathrm{H}-3^{\prime} / 5^{\prime}\right)$; $\delta_{\mathrm{H}}$ $\left.\left.7.44(1 \mathrm{H}, \mathrm{m}), \mathrm{H}-4^{\prime}\right)\right)$ and the second $p$-methoxy disubstituted $\left(\delta_{\mathrm{H}} 7.64(2 \mathrm{H}, \mathrm{d}, J=9.0 \mathrm{~Hz}), \mathrm{H}-\right.$ 2"/6"; $\left.\left.\delta_{\mathrm{H}} 6.96(2 \mathrm{H}, \mathrm{d}, J=9.0 \mathrm{~Hz}), \mathrm{H}-3 " / 5 "\right) ; \delta_{\mathrm{H}} 3.84(3 \mathrm{H}, \mathrm{s})\right)$. The remaining $\mathrm{C}_{3} \mathrm{HNO}$ and 3 double bond equivalents were accounted for as a 2,5-disubstituted-1,3-oxazole ring, with a correlation in the NOESY spectrum between the signals of $\mathrm{H}-4$ and H-2"/6" placing the $p$ - 
methoxy disubstituted ring at C-5. Uguenenazole, as the novel 5-(4"-dimethoxyphenyl)-2phenyl-1,3-oxazole) has structure (2) in Figure 1 below.

Balsoxine (5-(3,4-dimethoxyphenyl)-2-phenyl-1,3-oxazole), from Amyris balsamifera L. ((Burke et al., 1979), and its 3,4-methylenedioxy analogue texamine, from A. texana P. Wilson (Dominguez et al., 1988), are the only compounds with the 2,5-diphenyl-1,3-oxazole ring skeleton to have been isolated to date from natural sources. Even 2,5-diaryl-1,3-oxazole compounds are uncommon, with a further 14 examples only reported in the literature. Apart from phorbazoles A-D, four chlorinated-2-pyrrole derivatives from a Phorbas species of marine sponge (Rudi et al., 1994), all of the others have come from species of the Rutaceae (Dictionary of Natural Products, 2007).

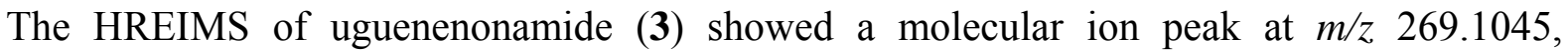
corresponding to the molecular formula $\mathrm{C}_{16} \mathrm{H}_{15} \mathrm{NO}_{3}$ and 10 double bond equivalents. Like (2), (3) also has two aromatic rings, one monosubstituted $\left(\delta_{\mathrm{H}} 7.86(2 \mathrm{H}, \mathrm{dd}, J=7.5,1.7 \mathrm{~Hz})\right.$, $\left.\left.\left.\mathrm{H}-2 / 6 ; \delta_{\mathrm{H}} 7.45(2 \mathrm{H}, \mathrm{dd}, J=7.5,7.5 \mathrm{~Hz}), \mathrm{H}-3 / 5\right) ; \delta_{\mathrm{H}} 7.51(1 \mathrm{H}, \mathrm{m}), \mathrm{H}-4\right)\right)$ and the second $p-$ methoxy disubstituted $\left(\delta_{\mathrm{H}} 8.00(2 \mathrm{H}, \mathrm{d}, J=8.0 \mathrm{~Hz}), \mathrm{H}-2^{\prime} / 6^{\prime} ; \delta_{\mathrm{H}} 6.97(2 \mathrm{H}, \mathrm{d}, J=8.0 \mathrm{~Hz}), \mathrm{H}-\right.$ $\left.\left.3^{\prime} / 5^{\prime}\right) ; \delta_{\mathrm{H}} 3.90(3 \mathrm{H}, \mathrm{s})\right)$. Also visible in the spectra of this compound were the signals of an amide carbonyl group $\left(\delta_{\mathrm{H}} 7.32\left(1 \mathrm{H}\right.\right.$, br s), $\left.3364 \mathrm{~cm}^{-1}, \mathrm{~N}-\mathrm{H} ; \delta_{\mathrm{C}} 167.4(\mathrm{C})\right)$, a ketone carbonyl group $\left(\delta_{\mathrm{C}} 192.6(\mathrm{C})\right)$, and an isolated methylene carbon $\left(\delta_{\mathrm{H}} 4.89(2 \mathrm{H}, \mathrm{s}) ; \delta_{\mathrm{C}} 46.5\left(\mathrm{CH}_{2}\right)\right)$. The downfield position of the signals of both $\mathrm{H}-2 / 6$ and $\mathrm{H}-2$ '/6' suggested that both aromatic rings had a benzylic carbonyl group, while correlations in the NOESY spectrum between the ${ }^{1} \mathrm{H}$ resonances of the methylene protons and $\mathrm{H}-2 \%$ ' on one hand, and between those of the amide proton and H-2/6 on the other, confirmed the structure as that of (3) in Figure 1.

Surprisingly, the $N$-benzoylbenzamide skeleton that characterizes uguenenonamide (3) has been reported only once previously, in the form of muricatisine from Oxytropis muricata (Pall.) DC. and O. puberula Boriss (Demeuov et al., 1999), two Asian members of the Fabaceae. This is the first report of both an azole such as (2) and its amide (3) precursor simultaneously being found, which is surprising as construction of the azole ring by Robinson-Gabriel dehydration of 2-acylaminoketones is a standard laboratory procedure (cf. eg. Brain and Paul, 1999; Nicolaou et al., 2004). 
The known compounds were identified as flindersiamine (4) (Chaturvedula et al., 2003), maculosidine (5) (Sekiba, 1973), and syringaldehyde (6) (Moodley, 2001) by comparison of their physical properties and spectral data with literature values.

As species of the Rutaceae (Watt and Breyer-Brandwijk 1962; Kokwaro 1976; Neuwinger 2000) and Meliaceae (MacKinnon et al., 1997) are frequently cited as antimalarials or febrifuges in African traditional medicine, and the antiplasmodial activity of a variety of both limonoids (Khalid et al., 1986; MacKinnon et al., 1997) and furoquinoline alkaloids (Basco et al., 1994) has previously been demonstrated, all six compounds were tested against the 3D7 (chloroquine susceptible, CQS) and FCM29 (chloroquine resistant, CQR) strains of $P$. falciparum. While compounds (2-4) were found to be completely inactive against both strains, (1), (5) and (6) displayed mild activity, with $\mathrm{IC}_{50}$ values of $10.4 \pm 4.4,29.2 \pm 3.2$, and $13.0 \pm 11.5 \mu \mathrm{g} . \mathrm{mL}^{-1}$, and 13.8 $\pm 1.0,40.4 \pm 3.6$, and $21.4 \pm 8.2 \mu \mathrm{g} \cdot \mathrm{mL}^{-1}$, against the CQS and CQR strains, respectively. No statistically significant difference between the activity against CQS and CQR strains was observed, except that of maculosidine (5), which was more active against the CQS 3D7 strain. 


\section{Experimental}

\subsection{General}

Melting points were determined on a Kofler micro-hot stage melting point apparatus and are uncorrected. NMR spectra were recorded at room temperature on a $400 \mathrm{MHz}$ Varian UNITYINOVA spectrometer. ${ }^{1} \mathrm{H}$ NMR spectra were referenced against the $\mathrm{CHCl}_{3}$ signal at $\delta_{\mathrm{H}} 7.27$, and ${ }^{13} \mathrm{C}$ NMR spectra against the corresponding signal at $\delta_{\mathrm{C}}$ 77.0. Coupling constants are given in Hz. Optical rotations were measured at room temperature in chloroform using a Perkin-Elmer 241 polarimeter with a $10 \mathrm{~cm}$ flow tube. IR spectra were recorded on a Nicolet Impact 400D Fourier-Transform Infrared (FT-IR) spectrometer, using $\mathrm{NaCl}$ windows with $\mathrm{CHCl}_{3}$ as solvent against an air background. UV spectra were obtained on a Varian DMS 300 UV-visible spectrometer. HREIMS were taken on a Micromass VG 70 SEQ instrument.

\subsection{Plant material}

The roots of Vepris uguenensis (157 g) were collected in the Barwessa Division, Baringo District, Kenya in July 2004. The plant was identified by Mr Ezekiel Cheboi of the Department of Natural Resources, Egerton University, Kenya. A voucher specimen (PKC 02, NH) has been retained at the Natal Herbarium, Durban.

\subsection{Extraction and isolation of compounds}

Air-dried, ground roots were left to stand in $\mathrm{CH}_{2} \mathrm{Cl}_{2}$ at room temperature for 5 days. The extract was decanted and concentrated to yield a crude extract ( $8.20 \mathrm{~g})$ which was separated using column chromatography over silica gel (Merck 9385) with a hexane/EtOAc step gradient (100:0 to 50:50). Further purification using the given solvent systems yielded the following; hexane/EtOAc (75:25) yielded methyl uguenesonate (1) (13.9 mg), $\mathrm{CH}_{2} \mathrm{Cl}_{2} / \mathrm{EtOAc}$ (95/5) yielded uguenenzole (2) (15.9 mg), $\mathrm{CH}_{2} \mathrm{Cl}_{2}$ (100) yielded uguenenonamide (3) (3.6 $\mathrm{mg}$ ) and maculosidine (5) (5.9 mg), hexane/EtOAc (85/15) yielded flindersiamine (4) (41.7 $\mathrm{mg}$ ), and $\mathrm{CH}_{2} \mathrm{Cl}_{2} / \mathrm{MeOH}$ (99/1) yielded syringaldehyde (6) (5.2 mg).

3.3.1 methyl uguenesonate (1): white crystals; m.p. $118-119{ }^{0} \mathrm{C} ; v_{\max }(\mathrm{NaCl}) \mathrm{cm}^{-1} 3405$, 2927, 1737, 1702, 1436, 1366, 1271, 1106, 1030; HREIMS (70 eV) 502.2206 (calc. for $\mathrm{C}_{27} \mathrm{H}_{34} \mathrm{O}_{9}$ 502.2203); EIMS (70 eV): m/z (rel. int.): 502 [M $\left.{ }^{+}\right], 487$ (2), 471 (2), 445 (9), 379 (100), $361(6), 321(4), 259$ (13), $201(10), 161(6), 103(17), 95(11), 43(18) ;[\alpha]_{\mathrm{D}}{ }^{25}+82.3(c$ $\left.=0.13, \mathrm{CHCl}_{3}\right) ;{ }^{1} \mathrm{H}$ NMR spectral data $\left(400 \mathrm{MHz}, \mathrm{CDCl}_{3}\right) \delta_{\mathrm{H}} 7.39(1 \mathrm{H}, \mathrm{s}, \mathrm{H}-21), 7.37(1 \mathrm{H}, \mathrm{s}$, 
H-23), 6.30 (1H, s, H-22), 5.57 (1H, s, H-17), 4.15 (1H, m, H-3), 3.99 (1H, m, H-19b), 3.91 (1H, s, H-15), 3.73 (1H, m, H-19a), 3.72 (3H, s, $\left.\mathrm{CO}_{2} \mathrm{C}_{3}\right), 2.97$ (1H, br s, H-9), 2.61 (1H, m,

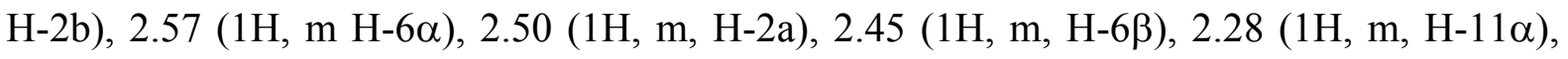

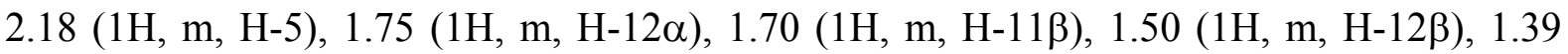
$(3 \mathrm{H}, \mathrm{s}, 3 \mathrm{H}-30), 1.24$ (3H, s, 3H-29), 1.17 (3H, s, 3H-18), $1.10(3 \mathrm{H}, \mathrm{s}, 3 \mathrm{H}-28) ;{ }^{13} \mathrm{C}$ NMR spectral data $\left(100 \mathrm{MHz}, \mathrm{CDCl}_{3}\right) \delta_{\mathrm{C}} 211.8(\mathrm{C}, \mathrm{C}-7), 173.6(\mathrm{C}, \mathrm{C}-1), 167.5(\mathrm{C}, \mathrm{C}-16), 143.1$ (CH, C-23), 141.1 (CH, C-21), 120.3 (C, C-20), 109.8 (CH, C-22), 83.8 (C, C-4), 78.1 (CH, C-17), 74.7 (CH, C-3), 69.5 (C, C-14), $68.7\left(\mathrm{CH}_{2}, \mathrm{C}-19\right), 55.4(\mathrm{CH}, \mathrm{C}-15), 52.3\left(\mathrm{CH}_{3}\right.$, $\left.\mathrm{CO}_{2} \underline{\mathrm{CH}}_{3}\right), 48.3(\mathrm{C}, \mathrm{C}-8), 39.5\left(\mathrm{CH}_{2}, \mathrm{C}-6\right), 39.3(\mathrm{C}-13), 36.9\left(\mathrm{CH}_{2}, \mathrm{C}-2\right), 35.6(\mathrm{CH}, \mathrm{C}-9), 28.9$ $\left(\mathrm{CH}_{3}, \mathrm{C}-29\right), 27.8\left(\mathrm{CH}_{2}, \mathrm{C}-12\right), 24.2\left(\mathrm{CH}_{3}, \mathrm{C}-28\right), 19.6\left(\mathrm{CH}_{3}, \mathrm{C}-18\right), 18.5\left(\mathrm{CH}_{2}, \mathrm{C}-11\right), 16.9$ $\left(\mathrm{CH}_{3}, \mathrm{C}-30\right)$.

3.3.2 uguenenazole (2): white crystals; m.p. 133-135 ${ }^{0} \mathrm{C}$; $(\mathrm{NaCl}) \mathrm{cm}^{-1} 3334,2927,2857$, 1690, 1607, 1507, 1466, 1260, 1177, 1030; HREIMS: 251.0948 (calc. for $\mathrm{C}_{16} \mathrm{H}_{13} \mathrm{O}_{2} \mathrm{~N}$ 251.0946); EIMS: m/z (rel. int.): $251\left[\mathrm{M}^{+}\right], 236$ (17), 220 (28), 214 (8), 208 (5), 196 (7), 181 (6), 153 (11), 152 (100), 149 (9), 136 (8), 135 (87), 132 (8), 129 (4), 125 (4), 122 (3), 121 (30), 111 (4), 109 (4), 107 (9), 106 (5), 105 (51), 92 (13), 89 (4), 83 (4), 81 (6), 78(7), 77 (59), 76 (6), 75 (4), 74 (5), 71 (5), 69 (4), 65 (6), 64 (9), 63 (11), 57 (9), 55 (7), 51 (20), 50 (8), 43 (8), 41 (6), 40 (8); UV $\lambda_{\max }\left(\mathrm{CHCl}_{3}\right) \mathrm{nm}(\log \varepsilon) 315$ (4.51); ${ }^{1} \mathrm{H}$ NMR spectral data $\left(400 \mathrm{MHz}, \mathrm{CDCl}_{3}\right) \delta_{\mathrm{H}} 8.08\left(2 \mathrm{H}, \mathrm{dd}, J=8.1,1.7 \mathrm{~Hz}, \mathrm{H}-2^{\prime} / 6\right.$ ') $7.64(2 \mathrm{H}, \mathrm{d}, J=9.0 \mathrm{~Hz}, \mathrm{H}-$ 2"/6”), $\delta_{\mathrm{H}} 7.46(2 \mathrm{H}, \mathrm{m}, \mathrm{H}-3$ '/5'), 7.44 (1H, m, H-4'), 7.30 (1H, s, H-4), 6.96 (2H, d, J = 9.0 $\mathrm{Hz}, \mathrm{H}-3 " / 5 ”), \delta_{\mathrm{H}} 3.84\left(3 \mathrm{H}, \mathrm{s},-\mathrm{OCH}_{3}\right) ;{ }^{13} \mathrm{C} \mathrm{NMR}$ spectral data $\left(100 \mathrm{MHz}, \mathrm{CDCl}_{3}\right) 160.6(\mathrm{C}, \mathrm{C}-$ 2), 159.8 (C, C-4”), 151.3 (C, C-5), 130.1 (CH, C-4'), 128.8 (CH, C-3'/5'), 127.6 (C, C-1'), 126.1 (CH, C-2'/6'), 125.7 (CH, C-2"/6”), 121.9 (CH, C-4), 120.9 (C, C-1”), 114.4 (CH, C$3 " / 5 "), 55.4\left(\mathrm{CH}_{3},-\mathrm{OCH}_{3}\right)$

3.3.3 uguenenonamide (3): white crystals; m.p. 106-108 ${ }^{0} \mathrm{C}$; $v_{\max }(\mathrm{NaCl}) \mathrm{cm}^{-1}: 3364,2927$, 2857, 1684, 1631, 1602, 1578, 1525, 1436, 1248, 1030; HREIMS: 269.1045 (calc. for $\mathrm{C}_{16} \mathrm{H}_{15} \mathrm{O}_{3} \mathrm{~N}$ 269.1051); EIMS: m/z (rel. int.): $269\left[\mathrm{M}^{+}\right], 258$ (8), 182 (5), 149 (6), 136 (9), 135 (100), 107 (3), 105 (14), 92 (5), 77 (17), 57 (4), 51 (4), 43 (4), 41 (3); UV $\lambda_{\max }\left(\mathrm{CHCl}_{3}\right) \mathrm{nm}$ ( $\log \varepsilon) 290$ (4.53); ${ }^{1} \mathrm{H}$ NMR spectral data $\left(400 \mathrm{MHz}, \mathrm{CDCl}_{3}\right) \delta_{\mathrm{H}} 8.00\left(2 \mathrm{H}, \mathrm{d}, J=8.0, \mathrm{H}-2{ }^{\prime} / 6\right.$ '), $7.86(2 \mathrm{H}, \mathrm{dd}, J=7.5,1.7 \mathrm{~Hz}, \mathrm{H}-2 / 6), 7.51(1 \mathrm{H}, \mathrm{m}, \mathrm{H}-4), 7.45(2 \mathrm{H}, \mathrm{dd}, J=7.5,7.5 \mathrm{~Hz}, \mathrm{H}-$ 3/5), 7.32 (1H, br s, N-프), 6.97 (2H, d, J = 8.0 Hz, H-3'/5'), 4.89 (2H, s, 2H-9), 3.90 (3H, s, $\left.\mathrm{OC}_{3}\right),{ }^{13} \mathrm{C}$ NMR spectral data $\left(100 \mathrm{MHz}, \mathrm{CDCl}_{3}\right) 192.6$ (C, C-10), 167.4 (C, C-7), 164.4 (C, 
C-4'), 134.0 (C, C-1), 131.7 (CH, C-4), 130.3 (CH, C-2'/6'), 128.6 (CH, C-3/5), 127.3 (C, C1'), 127.1 (CH, C-2/6), $114.2\left(\mathrm{CH}, \mathrm{C}-3\right.$ '/5'), $55.6\left(\mathrm{CH}_{3},-\mathrm{OCH}_{3}\right), 46.5\left(\mathrm{CH}_{2}, \mathrm{C}-9\right)$.

\subsection{In vitro antimalarial testing}

The chloroquine-sensitive 3D7 and chloroquine-resistant FCM29 strains of Plasmodium falciparum were maintained in continuous culture (Trager and Jensen, 1976) and used to assess the antiplasmodial activity of compounds isolated from $V$. uguenensis. The in vitro antiplasmodial testing was performed by use of the isotopic method as described elsewhere (Desjardins et al., 1979, Rason et al., 2007). Samples were tested in 96-well plates in triplicate at final concentrations of $64,16,8,4,2$, and $0.5 \mu \mathrm{g} / \mathrm{mL}$. We considered as inactive molecules with IC50 values $>64 \mu \mathrm{g} / \mathrm{ml}$. Student's t test was used for statistical comparison between mean IC50s. Difference was significant for $P$ values under 0.05 .

\section{Acknowledgments}

We thank Mr Dilip Jagjivan and Mr Bret Parel for the running of NMR and LRM spectra, respectively, Mr Tommy van der Merwe for provision of HRM spectra, Dr Marie Ange Rason and Mr Herilalaina Andrianantenaina for the cultivation of malaria parasites and in vitro antiplasmodial testing, and the South African National Research Foundation (NRF) and Institut Pasteur, via the project Fonds de Solidarité Prioritaire FSP/RAI 77003, for financial support.

\section{References}

Arnold, H.J., Gulumian, M., 1984. Pharmacopoeia of traditional medicine in Venda. Journal of Ethnopharmacology 12, 35-74.

Ayafor, J.F., Sondengam, B.L., Ngadjui, B.T., 1980. Veprisine and $N$ methylpreskimmianine: Novel 2-quinolones from Vepris louisii. Tetrahedron Letters 21, 3293-3294.

Ayafor, J.F., Sondengam, B.L., Ngadjui, B.T., 1981. The structure of veprisinium salt. Tetrahedron Letters 22, 2685-2688.

Ayafor, J.F., Sondengam, B.L., Ngadjui, B.T., 1982a. Veprisinium salt, a novel antibacterial quaternary alkaloid from Vepris louisii. Planta Medica 44, 139-142. 
Ayafor, J.F., Sondengam, B.L., Ngadjui, B.T., 1982b. Veprisilone, a prenylated 2-quinolone, and limonin from Vepris louisii. Phytochemistry 21, 955-956.

Ayafor, J.F., Sondengam, B.L., Ngadjui, B.T., 1982c. Quinoline and indolopyridoquinazoline alkaloids from Vepris louisii. Phytochemistry 21, 2733-2736.

Basco, L.K., Mitaku, S., Skaltsounis, A.L., Ravelomanantsoa, N., Tillequin, F., Koch, M., Le Bras, J., 1994. In vitro activities of furoquinoline and acridone alkaloids against Plasmodium falciparum. Antimicrobial Agents and Chemotherapy 38, 1169-1171.

Billet, D., Favre-Bonvin, J., 1973. Constituants de l'huile essentielle de Vepris madagascarica. Phytochemistry 12, 1194.

Brader, G., Bacher, M., Greger, H., Hofer, O., 1996. Pyranoquinolones and acridones from Vepris bilocularis. Phytochemistry 42, 881-884.

Brain, C.T., Paul, J.M., 1999. Rapid synthesis of oxazoles under microwave conditions. Synlett 1642-1644.

Burke, B., Parkins, H., Talbot, A.M., 1979. An oxazole and its precursor in Amyris balsamifera. Heterocycles 12, 349-51.

Chaturvedula, V.S.P., Schilling, J.K., Miller, J.S., Andriantsiferana, R., Rasamison, V.E., Kingston D.G.I., 2003. New cytotoxic alkaloids from the wood of Vepris punctata from the Madagascan rainforest. J. Nat. Prod. 66, 532-534.

Chhabra, S.C., Mahunnah, R.L., Mshiu, E.N., 1991. Plants used in traditional medicine in eastern Tanzania. V. Angiosperms (Passifloraceae to Sapindaceae). Journal of Ethnopharmacology 33, 143-57.

Dagne, E., Yenesew, A., Waterman, P.G., Gray, A.I., 1988. The chemical systematics of the Rutaceae, subfamily Toddalioideae, in Africa. Biochemical Systematics and Ecology 16, 179-188.

Demeuov, N.B., Akhmedzhanova, V.I., Moldagulov, M.A., Shakirov, R.S., 1999. Muricatisine, a new alkaloid from two species of Oxytropis. Chemistry of Natural Compounds 34, 484-485.

Desjardins. R.E., Canfield, C.J., Haynes, J.D., Chulay, J.D., 1979. Quantitative assessment of antimalarial activity in vitro by a semiautomated microdilution technique. Antimicrob Agents Chemother 16, 710-718.

Dictionary of Natural Products on CD-ROM, 2007. Chapman Hall/CRC Press/Hampden Data Services, Ltd.

Dominguez, X.A., De la Fuente, G., Gonzalez, A.G., Reina, M., Timon, I., 1988. Two new oxazoles from Amyris texana P. Wilson. Heterocycles 27, 35-38. 
Ganguly, A.K., Govindachari, T.R., Manmade, A., Mohamed, P.A., 1966. Alkaloids of Vepris bilocularis. Indian Journal of Chemistry 4, 334-335.

Gessler, M.C., Msuya, D.E., Nkunya, M.H., Mwasumbi, L.B., Schar, A., Heinrich, M., Tanner, M., 1995. Traditional healers in Tanzania: the treatment of malaria with plant remedies. Journal of Ethnopharmacology 48, 131-44.

Gessler, M.C., Nkunya, M.H., Mwasumbi, L.B., Heinrich, M., Tanner, M., 1994. Screening Tanzanian medicinal plants for antimalarial activity. Acta tropica 65-77.

Gomes, E., Dellamonica, G., Gleye, J., Moulis, Cl., Chopin, M.J., Stanislas, E., 1983. Phenolic compounds from Vepris heterophylla. Phytochemistry 22, 2628-2629.

Gomes, E.T., Travert, S., Gleye, J., Moulis, C., Fouraste, I., Stanislas, E., 1994. Furoquinoline alkaloids from Vepris heterophylla. Planta Medica 60, 388.

Govindachari, T.R., Joshi, B.S., Sundararajan, V.N., 1964. Structure of veprisone, a constituent of Vepris bilocularis. Tetrahedron 20, 2985-2990.

Govindachari, T.R., Sundararajan, V.N., 1961. Alkaloids of Vepris bilocularis. Journal of Scientific and Industrial Research 20B, 298-299.

Gurib-Fakim, A., Sewraj, M., Gueho, J., Dulloo, E., 1993. Medical ethnobotany of some weeds of Mauritius and Rodrigues. Journal of Ethnopharmacology 39, 175-85.

Haensel, R., Cybulski, E.M., 1978. Alkaloids from the root bark of Vepris pilosa. Archiv der Pharmazie (Weinheim, Germany) 311, 135-138.

Hedberg, I., Hedberg O., Madati P.J., Msigeni, K.E., Mshiu E.N., Samuelsson G., 1983 . Inventory of plants used in traditional medicine in Tanzania. Part III. Plants of the families Papilionaceae-Vitaceae. Journal of Ethnopharmacology 9, 237-260.

Kan-Fan, C., Das, B.C., Boiteau, P., Potier, P., 1970. Alcaloïdes de Vepris ampody (Rutacées). Phytochemistry 9, 1283-1291.

Khalid, S.A., Farouk, A., Geary, T.G., Jensen, J.B., 1986. Potential antimalarial candidates from African plants: and an in vitro approach using Plasmodium falciparum. Journal of Ethnopharmacology 15, 201-209.

Khalid, S.A., Waterman, P.G., 1982. Chemosystematics in the Rutaceae. 15. Furoquinoline and pyrano-2-quinolone alkaloids of Vepris stolzii. Journal of Natural Products 45, 343-346.

Koffi, Y., Gleye, J., Moulis, C., Stanislas, E., 1987. Acridones from Vepris fitoravina and Vepris macrophylla. Planta Medica 53, 570.

Kokwaro, J.O., 1976. Medicinal plants of East Africa. East African Literature Bureau, Nairobi. 
MacKinnon S, Durst T, Arnason JT, Angerhofer C, Pezzuto J, Sanchez-Vindas PE, Poveda LJ, Gbeassor M., 1997. Antimalarial activity of tropical Meliaceae extracts and gedunin derivatives. Journal of Natural Products 60, 336-341.

Moodley, B., 2001. Characterisation of SAPPI-Saicor's Pulp Mill Effluent. MSc Thesis, University of Natal, Durban, pp. 64-69.

Moulis, C., Fouraste, I., Keita, A., Bessiere, J. M., 1994. Composition of the leaf essential oil from Vepris heterophylla R.Let. Flavour and Fragrance Journal 9, 35-37.

Neuwinger, H.D., 2000. African traditional medicine: a dictionary of plant use and applications. Medpharm Scientific Publishers, Stuttgart, Germany, p. 589.

Ng, K.M., Gray, A.I., Waterman, P.G., But, P.P.H., Kong, Y.C., 1987. Limonoids, alkaloids, and a coumarin from the root and stem barks of Tetradium glabrifolium. Journal of Natural Products 50, 1160-1163.

Ngadjui, T.B., Ayafor, J.F., Sondengam, B.L., Connolly, J.D., ; Rycroft, D.S., Khalid, S.A., Waterman, P.G., Brown, N.M.D., Grundon, M.F., Ramachandran, V.N., 1982. The structures of vepridimerines A-D, four new dimeric prenylated quinolone alkaloids from Vepris louisii ad Oricia renieri (Rutaceae). Tetrahedron Letters 23, 2041-2044.

Nicolaou, K.C., Hao, J., Reddy, M.V., Rao, P.B., Rassias, G., Snyder, S.A., Huang, X., Chen, D.Y-K., Brenzovich, W.E., Giuseppone, N., Giannakakou, P., O'Brate, A., 2004. Chemistry and Biology of Diazonamide A: Second Total Synthesis and Biological Investigations. Journal of the American Chemical Society 126, 12897-12906.

Patra, A., Misra, S.K., Chaudhuri, S.K., 1988. Constituents of Limonia acidissima. Applications of two-dimensional NMR spectroscopy in structure elucidation. Journal of the Indian Chemical Society 65, 205-208.

Poitou, F., Masotti, V., Viano, J., Gaydou, E.M., Andriamahavo, N.R., Mamitiana, A., Rabemanantsoa, A., Razanamahefa, B.V., Andriantsiferana, M., 1995. Chemical Composition of Vepris elliotii essential oil. Journal of Essential Oil Research 7, 447-449.

Rakotondraibe, L.H.R., Rakotovao, M., Ramanandraibe, V., Ravaonindrina, N., Frappier, F., Brouard, J-P., 2001. Composition and antimicrobial activity of leaf oils of Vepris leandriana H. Perr. Journal of Essential Oil Research 13, 467-469.

Rasoanaivo, P., Federici, E., Palazzino, G., Galeffi, C., 1999. Acridones of Vepris sclerophylla: their ${ }^{13} \mathrm{C}$ NMR data. Fitoterapia 70, 625-627.

Rason, M.A., Andrianantenaina, H.B., Ariey, F., Raveloson, A., Domarle, A., Randrianarivelojosia, M., 2007. Prevalent pfmdr1 N86Y mutant Plasmodium falciparum in 
Madagascar despite absence of pfcrt mutant strains. American Journal of Tropical Medicine and Hygiene 76, 1079 - 1083.

Rudi, A., Stein, Z., Green, S., Goldberg, I., Kashman, Y., Benayahu, Y., Schleyer, M., 1994. Phorbazoles A-D, novel chlorinated phenylpyrrolyloxazoles from the marine sponge Phorbas aff. clathrata. Tetrahedron Letters 35, 2589-2592.

Sekiba, T., 1973. New syntheses of maculosidine and pteleine. Bulletin of the Chemical Society of Japan 46, 577-80.

Sidibe, L., Chalchat, J-C., Garry, R-P., Harama, M., 2001. Aromatic plants of Mali. VI. Chemical composition of essential oil of Vepris heterophylla (Engl.).

Steenkamp, V., 2003. Traditional herbal remedies used by South African women for gynaecological complaints. Journal of Ethnopharmacology 86, 97-108.

Trager W., Jensen J.B., 1976. Human malaria parasites in continuous culture. Science 193, 673-675.

Vera, R., Smadja, J., Conan, J.Y., 1990. Preliminary screening of alkaloid-containing plants of Reunion. Plantes Medicinales et Phytotherapie 24, 50-65.

Watt, J.M., Breyer-Brandwijk, M.G., 1962. Medicinal and poisonous plants of southern and eastern Africa. E \& S Livingstone Ltd., London and Edinburgh.

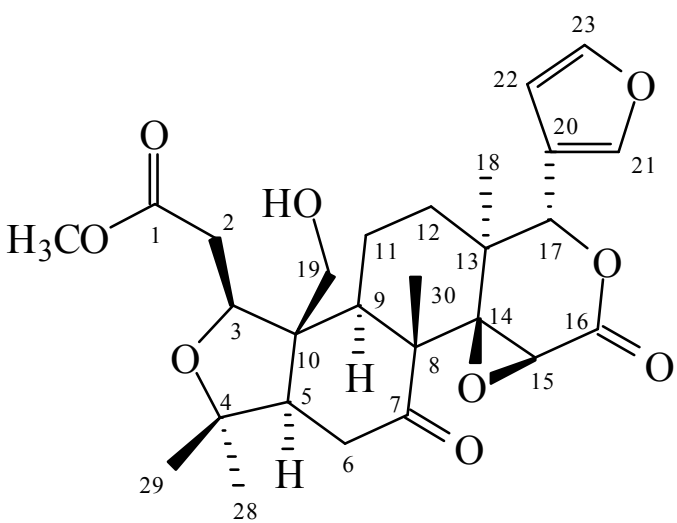

methyl uguenesonate (1)

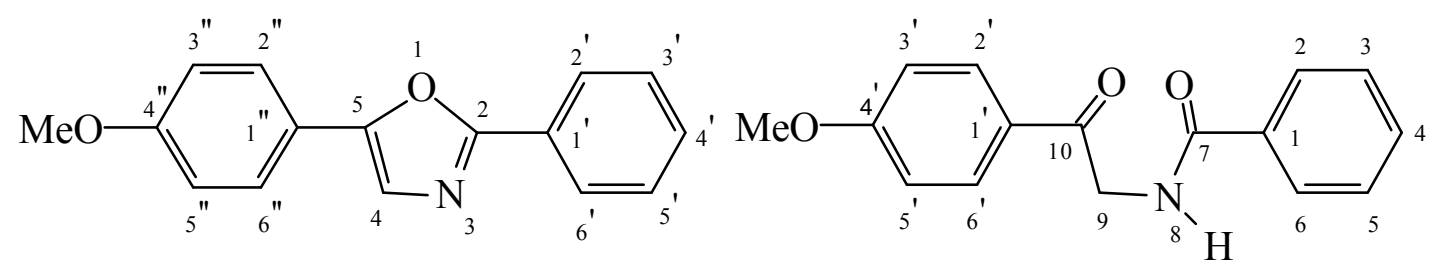

unguenenazole (2)

unguenenonamide (3)

Figure 1: Isolates from Vepris uguenensis 